\title{
Colorectal Angiosarcoma
}

National Cancer Institute

\section{Source}

National Cancer Institute. Colorectal Angiosarcoma. NCI Thesaurus. Code C96511.

An angiosarcoma that arises from the colon or rectum. 